\title{
Contents, Vol. 22, 1983
}

Founded 1897 as 'Monatsschrift fur Psychiatric und Neurologic', continued 1957-1967 as 'Psychiatria et Neurologia' Founders: C. Wernicke and Th. Ziehen. Successors: K. Bonhoeffer (1912-1938), J. Klaesi (1939-1967), E. Grînthal Founded 1897

Editor-in-Chief

H.E. Kaescr, Basel

Associate Editors C. Locb, Genova H.-G. Mertens, Wurzburg U.K. Rinne, Turku H. vander Ečcken, Ghent

Editorial Board

L. Barraquer Boardas, Barcelona

J. Droogleever Fortuyn, Groningen

S. Feldman, Jerusalem

P. Huber, Bern

A. Kreindler, Bucharest

H.J. Lehmann, Esse

C. Pallis, London
P. Passouant, Montpellier

P. Passouant, Montpellier
E. Satoyoshi, Tokyo

F. Seitelberger, Vienna

Advisory Board

G.G. Brune, Minister

Electromyography H.P. Ludin, Bern

Neuroendocrinology

P.O. Lundberg, Uppsala

Neuropsychology E. Perret, Zurich

Cerebrospinal Fluid H.B. Rieder, Basel

Electroencephalography

G. Scollo-Lavizzari, Base

Evoked Potentials

W. Tackmann, Bonn

\section{wmm}

Contents Vol. 22,1983 
No. 1 Human Alphal -Microglobulin Levels in Neurological Disorders

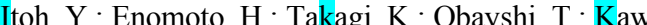

First Clinical Investigation of the Benzodiazepine Antagonist Ro 15-1788 in Comatose

Patients

Scollo-Lavizzari, G

Cerebrospinal Fluid Cyclic Adenosine 3',5'-Monophosphate in Cases of Severe Cerebral

Ischemia and Meningitis

Papageorgiou, C; Gyftaki, H.; Mavrikakis, M.; Kesse-Elias, M.; Alevizou-Terzaki, V.;

Kondou, 1

Multiple Sclerosis-Specific Central Nervous System Antigens (MSG2): A Blind Study

Rastogi, S.C.; Clausen, J.; Tourtellotte, W.W.; Potvin, A.R

Facilitating Myasthenic Syndrome and Quadriceps Myopathy

Alberca, R.; Gil-Peralta, A.; Castilla, J.M.; Rafel, E.; Bautista, J............................................ 22

Effect of Dantrolene Sodium in Myotonic Dystrophy

Mamoli, B.; Dai-Bianco, P.; Zeitlhofer, K....

Clinical and CSF Findings in Multiple Sclerosis Patients with or without IgG Oligoclonal

Bands at Isoelectric Focusing Examination of CSF and Serum Proteins

Rocchelli, B.; Poloni, M.; Mazzarello, P.; Delodovici, M....

Infantile Epilepsy with Occipital Focus and Good Prognosis

Beaumanoir, A

Mitochondrial Function in Myasthenia gravis

Lousa, M.; Gobernado, J.M.; Gimeno, A.; Gosalvez, M

Progressive Idiopathic Strio-Pallido-Dentate Calcinosis (Fahr's Disease) with Autosomal

Recessive Inheritance. Report of Three Siblings

Smits, M.G.; Gabreels, F.J.M.; Thijssen, H.O.M.; 't Lam, R.L.; Notermans, S.L.H.; ter

Haar, B.G.A.; Prick, J.J

Adenylate Kinase Activity of Cerebrospinal Fluid in Central Nervous System Disorders

Unger, W.; Toifl, K.; Bohm, M.P.; Bayer, P.M ...

Unilateral Scapulohumeral Muscular Atrophy

Kaeser, H.E; Feinstein, R ; Tackman, W

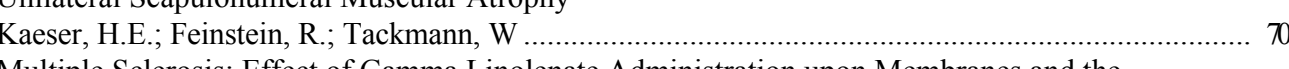

Need for Extended Clinical Trials of Unsaturated Fatty Acids

Field, E.J.; Joyce, G

Book Review

No. 2 Trace Elements in Whole Blood of Multiple Sclerosi

Rieder, H.P.; Schoettli, G.; Seiler, H

A Case of Aphasia following Left Thalamic Hemorrhage

Papagno, C; Guidotti, M

Contents

The Concentration of Prealbumin in Cerebrospinal Fluid (CSF), Indicator of CSF Circulation Disorder

Weisner, B.; Roethig, H.-

Amyloid Neuropathy and Multiple Myeloma. Ultrastructural and Immunopathological

Study of Two Cases

Vital, C; Lacoste, D.; Deminiere, C; Lagueny, A.; Boisseau, C; Reiffers, J.; Amouretti,

$\mathrm{M}$; Broustet, A

Sechi, G.P.; Traccis, S.; Durelli, L.; Monaco, F.; Mutani, R..............................................................113

Further Studies with Lisuride in Parkinson's Disease

Lieberman, A.N.; Goldstein, M.; Gopinathan, G.; Leibowitz, M.; Neophytides, A.;

Walker, R.; Hiesiger, E.

Angiographic Findings in Relation to Clinical Course and Results of Computed Tomography

in Cerebric

in Cerebrovascular Disease

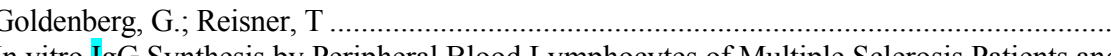

Normal Individuals. Effect of Multiple Sclerosis and Non-Multiple Sclerosis Brain Antigens

Rastogi, S.C.; Birkebcek, N.H

Pasteurella ureae Meningitis Associated with Endocarditis. Report of a Case and Review of

the Literature

Brass, E.P ; Wray, L M ; McDuff, T

Cerebro-Circulatory Effects of So-Called 'Vasodilators' in the Anaesthetised Rat

Young, A.R.; Barry, D.I.; MacKenzie, E.T.; Robert, J.-P

.154

No. 3 Recurrent Alternating Ophthalmoplegia with Iridoplegia in a Young Diabetic 
Central Conduction Velocity (Lumbar-Vertex) in Man Calculated by Means of a New Meth

od. Studies on Variability, the Effects of Sex, Age and Different Equipments

Rossini, P.M.; Treviso, M

Biopsy Study

Pages, M.; Pages, A.-M ....

Incidence of Abnormal EEG Findings in Patients with Obstructions of the Carotid Artery

and Their Prognostic Value for the Postoperative Long-Term Course

Grobe, T.; Fliigel, K.A.; Klupp, M....

Combined Partial Temporal and Secondary Generalized Status Epilepticus. Report of a Case

with Fear Bouts Followed by Prolonged Confusion

Zappoli, R.; Zaccara, G.; Rossi, L.; Arnetoli, G.; Amantini, A

First Results of Immunotherapy with Immunoglobulin G in Multiple Sclerosis Patients

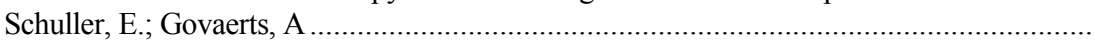

Prealbumin and Immunoglobulin in Serum and Cerebrospinal Fluid in Familial Amyloid

Polyneuropathy

Shoji, S.; Adachi, N.; Kameko, M.; Nakagawa, S

Familial Paroxysmal Kinesigenic Choreoathetosis. Report of a Pharmacological Trial in 2

Cases

Garello, L.; Ottonello, G.A.; Regesta, G.; Tanganelli, P

Sensorimotor Neuropathy in a Patient with Marinesco-Sjogren Syndrome

Alexianu, M.; Christodorescu, D.; Vasilescu, C; Dan, A.; Petrovici, A.; MiSgureanu, S.;

Savu, C

Eating Seizures

Eating Seizures

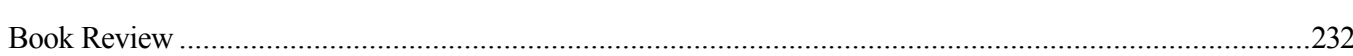

No. 4 Mitral Valve Prolapse as a Risk Factor for TIA. A Study with Echocardiography and Dynamic ECG

Fieschi, C; Francia, A.; Allori, L.; Argentino, C; Bernardi, S.; Bertazzoni, G.; Carpinteri, F.; Di Piero, V.; Ferroluzzi, M.; Lenzi, G.L.; Prencipe, M.; Servi, M.; Zanette, E. . . 233 Lisuride in the Treatment of Parkinsonism

McDonald, R.J.; Horowski, R

240

Nontraumatic Dissecting Aneurysm of the Basilar Artery

Bugiani, O.; Piola, P.; Tabaton, M........................................................................................................2 256

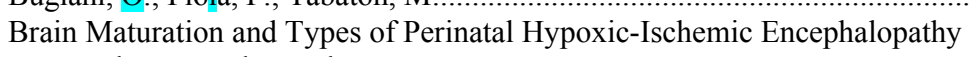

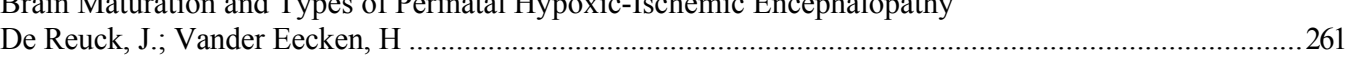

Beta-Endorphin, Beta-Lipotropin and Adrenocorticotropic Hormone Levels in Cerebrospinal Fluid, and Brain Damage in Chronic Alcoholics

Savoldi, F.; Mazzella, G.L.; Facchinetti, F.; Nappi, G.; Petraglia, F.; Sinforiani, E.; Par-

rini, D.; Genazzani, A.R

.265

Role of Penicillamine for the Induction of Myasthenia gravis

Smith, CLE · Hammarstrom, L : Matell, G.; Nilsson, B.Y

Skin Fibroblasts in Huntington's Disease. An Electron Microscopic Study

Leonardi, A.; Mancardi, G.L.; Gherardi, G.F.; Cocito, L.; De Martini, I.; Tabaton, M. 283

Chronic Lymphocytic Leukemia: Study of Cell Subsets in Cerebrospinal Fluid and Periph

eral Blood

Poltorak, M.; Czlonkowska, A.; Nowicka, K

.289

Spontaneous Thrombosis of an Aneurysm of the Great Vein of Galen

Di Rocco, C; Iannelli, A,; Puca, A,; Colosine, Gre Jr...

Announcements

No. 5 Encephalopathy, Peripheral Neuropathy, Dysautonomia, Myasthenia gravis, Malignant

Thymoma, and Antiacetylcholine Receptor Antibodies in the CSF

Bogousslavsky, J.; Regli, F.; Doret, A.M.; Fulpius, B.W.; Ostinelli, B.; Rabinowicz, T.;

Ruzicka, J

Detection of Circulating Immune Complexes Associated with Brain Tumors. Correlation

with Histological Differentiation and Length of Clinical History

wauro, G.M.; Grossi, M.; Di Lorenzo, N

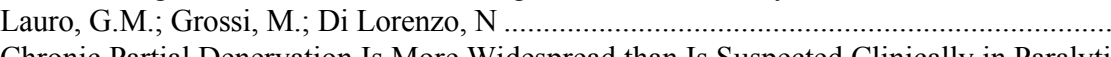

Poliomyelitis. Electrophysiological Study

Cruz Martinez, A.; Perez Conde, M.C.; Ferrer, M.T

Contents

$\mathrm{V}$

Spectral Analysis of Ail-Night Sleep EEG in Healthy Adult

Dumermuth, G.; Lange, B.; Lehmann, D.; Meier, C.A.; Dinkelmann, R.; Molinari, L.. 322 Modifications of the Erythrocyte Membrane Phospholipids in a Family with Cerebellar 


\section{Ataxia}

Gallai, V.; Firenze, C.

Epilepsies with Diffuse Slow Spikes and Waves of Late Onset

Prognosis of Symptomatic Intracranial Obstruction of Internal Carotid Artery

Bogousslavsky, J.; Regli, F....

Periodic EEG Discharges in Psychiatry

Sweden, B. van; Hoste, S

Cerebral Glutamate, Neuroleptic Drugs and Schizophrenia: Increase of Cerebrospinal Fluid

Glutamate Levels and Decrease of Striate Body Glutamate Levels following Sulpiride

Treatment in Rats

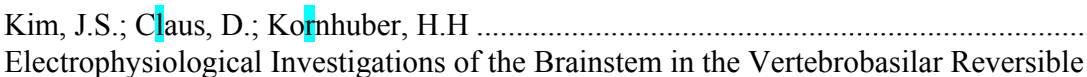

Attacks

Rossi, L.; Amantini, A.; Bindi, A.; Pagnini, P.; Arnetoli, G.; Zappoli, R.

Rossi, L.; Amantini, A.; Bindi, A.; Pagnini, P.; Arnetoli, G.; Zappoli, R...............................

Frass, M.; Toifl, K.; Leixnering, W

Book Reviews

No. 6 Influence of Human Allergic Encephalitogenic Peptide on Platelet Aggregation in Multiple Sclerosis

Prosiegel, M.; Neu, I.S

Impairment of Smooth Pursuit Eye Movement in Chronic Alcoholics

Kobatake, K; Yoshii, F.; Shinohara, Y.; Nomura, K.; Takagi, S .....

Application of Electrophysiological Methods in the Diagnosis of Cervi

cal Root Compressions

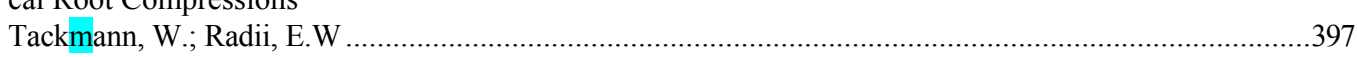

Parkinsonian Syndrome after Methanol Intoxication

Long-Term Therapy with Carbamazepine: Effects on Nerve Conduction Velocity

Traccis, S.; Monaco, F.; Sechi, G.P.; Moglia, A.; Mutani, R

$\ldots 410$

Focal Tuberculous Meningoencephalitis

Trautmann, M; Lindner, O; Haase, C; Bruckner, $0 \ldots .$.

Hemodynamics in Shy-Drager Syndrome and Treatment with Indometacin

Tsuda, Y.; Kimura, K.; Yoneda, S.; Asai, T.; Handa, N.; Tanouchi, J.; Inoue, M.; Abe, H. 421

Subacute Sclerosing Panencephalitis in Only One of Identical Twins. Case Report with Study

of Cell-Mediated Immunity

Cianchetti, C; Marrosu, M.G.; Manconi, P.E.; Loi, M.; Cao, A

Axo-Axonic Synapses in the Rat Striatum

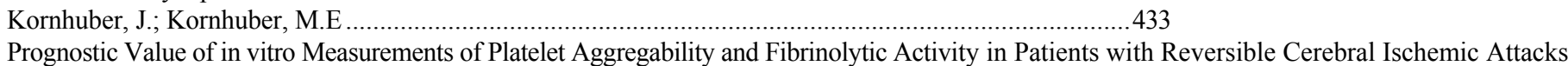

Prognostic Value of in vitro Measurements of Platelet Aggregability and Fibrinolytic Activity
Soelberg Sorensen, P.; Agerkov Andersen, L.; Gormsen, J.; Pedersen, H.; Marquardsen,

J.; Petersson, H.; Heltberg, A.; Simonsen, N.; Munck, 0 .

Contents

Blood Cells Glutathione Peroxidase Activity and Selenium in Multiple Sclerosis

Mazzella, G.L.; Sinforiani, E.; Savoldi, F.; Allegrini, M.; Lanzola, E.; Scelsi, R. 442

Computer Tomographic Evaluation of Cervical Astrocytoma

Nahser, H.C.; John, V.; Nau, H.-E.; Reinhardt, V.

Book Reviews

Author Index

453

Subject Index.

Suppl. 1 Importance of Hemorheologic Aspects in the Diagnosis and Treatment of Ischemic

Cerebrovascular Disease

XVİth Venetian Symposium, May 25-30, 1982 Editors: H. Lechner, D. Fontanari, H. Kugler, E. Ott

Suppl. 2 Effects of Aging on Regulation of Cerebral Blood Flow and Metabolism.

Abstracts Ind Satellite Symposium, San Remo (Italy), 30th June, 1st July, 1983 Editors: C. Fieschi, C.W. Loeb 
Drug Dosage

The authors and the publisher have exerted every effort to ensure that drug selection and dosage set forth in this text are in accord with current recommendations and practice at the time of publication. However, in view of ongoing research, changes precautions. This is particularly important when the recommended agent is a new and/or infrequently employed drug.

All rights reserved.

No part of this publication may be translated into other languages, reproduced or utilized in any form or by any means, electronic or mechanical, including photocopying, recording, microcopying, or by any information storage and retrieva system, without permission in writing from the publisher or, in the case of photocopying, direct payment of a specified fee to the Copyright Clearance Center (see 'Information for Readers and Subscribers').

(c) Copyright 1983 by S. Karger AG,

Printed in Switzerland by Thiir AG Offsetdruck, Pratteln 